\title{
MICRO-ENCAPSULATED PHASE-CHANGE MATERIALS FOR LATENT-HEAT STORAGE: THERMAL CHARACTERISTICS
}

\author{
MIKROENKAPSULIRANI MATERIALI S FAZNO PREMENO ZA \\ SHRANJEVANJE LATENTNE TOPLOTE: TOPLOTNE \\ ZNAČILNOSTI
}

\author{
Milan Ostrýㅁ, Darina Dostálová ${ }^{1}$, Tomáš Klubal ${ }^{1}$, Radek Přikryl ${ }^{2}$, Pavel Charvát ${ }^{3}$ \\ ${ }^{1}$ Brno University of Technology, Faculty of Civil Engineering, Institute of Building Structures, Veveří 95 , 60200 Brno, Czech Republic \\ 2Brno University of Technology, Faculty of Chemistry, Purkyňova 464/188, 61200 Brno, Czech Republic \\ ${ }^{3}$ Brno University of Technology, Faculty of Mechanical Engineering, Technická 2, 61669 Brno, Czech Republic \\ ostry.m@fce.vutbr.cz
}

Prejem rokopisa - received: 2013-10-01; sprejem za objavo - accepted for publication: 2014-11-24

doi:10.17222/mit.2013.210

\begin{abstract}
A significant problem of the utilization of renewable energy is the mismatch between the demand and availability. From this point of view, heat storage contributes to the use of renewable energy for the heating and cooling of buildings. Heat can be stored using sensible- or latent-heat-storage techniques. Nowadays, activated concrete structures are used as an alternative cooling-and-heating system. Light-weight timber structures with an equivalent heat-storage capacity can be used instead of these heavy-weight structures. The latent-heat storage using micro-encapsulated phase-change materials (PCMs) represents a way to provide an adequate thermal mass within a small thickness of thermally activated structures. A series of experiments in a $\mathrm{lab}$ and test rooms were carried out to investigate the thermal behavior of micro-encapsulated PCMs for building applications. The Micronal@DS 5040 X microencapsulated PCM was used as the latent-heat-storage medium in combination with gypsum plaster. Differential scanning calorimetry (DSC) was used for a thermal analysis of the latent-heat storage medium. The storage medium underwent thermal cycling for an assessment of the heat-storage capacity changes during the proposed service life. The floor structure and the plasterboards fixed onto the ceiling and walls of an experimental room with an integrated PCM were thermally activated with capillary tubes. The performance of the system was continuously observed and evaluated.

Keywords: phase-change materials (PCMs), latent-heat storage (LHS), differential scanning calorimetry (DSC), thermal cycling, building, thermal capacity

Pomemben problem pri izkoriščanju obnovljive energije je neskladje med potrebo in razpoložljivostjo. S tega vidika shranjevanje toplote prispeva $\mathrm{k}$ uporabi obnovljive energije pri ogrevanju in hlajenju zgradb. Toplota se lahko smiselno shrani s tehniko shranjevanja latentne toplote. Danes se uporabljajo aktivirane betonske strukture kot alternativni ogrevni ali ohlajevalni sistemi. Lahke lesene strukture $\mathrm{z}$ enakovredno kapaciteto shranjevanja toplote se lahko uporabijo namesto teh težkih struktur. Shranjevanje latentne toplote $z$ uporabo mikroenkapsuliranega materiala s fazno premeno (PCM) je način za zagotovitev ustrezne količine toplote kljub majhni debelini toplotno aktiviranih zgradb. Izvršena je bila serija preizkusov v laboratoriju in v preizkusnih sobah za ugotovitev toplotnega vedenja mikroenkapsuliranega PCM za uporabo pri zgradbah. Kot medij za shranjevanje latentne toplote je bil uporabljen mikroenkapsulirani PCM Micronal®DS $5040 \mathrm{X}$ v kombinaciji z ometom iz mavca. Diferenčna vrstična kalorimetrija (DSC) je bila uporabljena za toplotno analizo medija za shranjevanje latentne toplote. Shranjevalni medij je bil izpostavljen toplotnim ciklom za ugotovitev sprememb kapacitete shranjene toplote med predlaganim delovanjem. Tla in mavčne plošče z vgrajenim PCM, pritrjene na strop in stene eksperimentalne sobe, so bile toplotno aktivirane s kapilarnimi cevkami. Vedenje sistema je bilo opazovano in ocenjeno.

Ključne besede: materiali s fazno premeno (PCM), latentno shranjevanje toplote (LHS), diferenčna vrstična kalorimetrija (DSC), toplotno cikliranje, zgradba, toplotna kapaciteta
\end{abstract}

\section{INTRODUCTION}

Heat storage can be in the forms of sensible heat in a liquid or solid medium, heat of fusion, chemical energy or products in a reversible chemical reaction. ${ }^{1}$ Latentheat storage represents a more efficient form of heat storage compared to sensible-heat storage due to a high storage capacity per volume or mass. Common storage media, e.g., brick walls or concrete structures, can store heat only through an increase in their temperature. This is a problem when the required change in ambient temperature is narrow. A typical example is indoor climate in buildings. The occupants require a stable indoor climate with very low changes in the temperature during the year. The heat-storage capacity of a building enve- lope helps to maintain the indoor air temperature in the required range without additional cooling and heating systems. This principle is strongly dependent on the potential of heat loses or heat gains. Building envelopes of modern office buildings are made of light-weight materials. Regarding the thermal comfort, the main disadvantages of light-weight structures are their low thermal mass, low thermal inertia and a potential comfort problem such as overheating. ${ }^{2}$

Therefore, light-weight building materials with a high heat-storage capacity represent a way of decreasing the energy consumption and operating cost.

Phase-change materials (PCMs) are latent-heat-storage media. The PCMs are able to store large amounts of heat during the melting process. The solidifying process 
is accompanied by a release of the stored heat. The PCMs should have the melting and solidification temperature range in the practical range of an application and they need to have a high latent heat of fusion and a high thermal conductivity for the effective thermal storage $^{2}$.

There are some possible techniques to integrate PCMs directly into the building materials: ${ }^{3}$

- a simple immersion of a porous material in a liquid PCM;

- a vacuum impregnation of a PCM in the porous aggregates of a building material;

- a direct mixing of an encapsulated PCM into concrete or plaster during a concrete or plaster mixing.

Microcapsules are small containers encapsulating a PCM that can be mixed with many building materials. Micro-encapsulation is a process in which PCM particles are surrounded or coated with a continuous film of a polymeric material to produce capsules in a micrometer to millimeter range. ${ }^{4}$ The PCM forms the core and the polymeric material creates the shell. The microcapsules are usually of a spherical shape though other shapes are also possible. The microcapsules allow for the volume changes of the PCM, reducing the reaction of the PCM with the outside environment. ${ }^{5}$ This technology of encapsulation increases the heat-transfer area and allows for an easier handling of PCMs. There is no risk of a massive leakage of the PCMs since the PCM volume in a capsule is very small. The building structures with incorporated PCMs are similar to the commonly used building materials. The micro-encapsulation can be carried out with physical or chemical methods. ${ }^{4}$ The physical methods are: pan coating, air-suspension coating, centrifugal extrusion, vibrational nozzle and spray drying. There are several chemical methods: interfacial polymerization, in-situ polymerization and matrix polymerization.

\section{MATERIAL AND METHODS}

There are several important aspects of a practical use of the latent-heat-storage technology:

- the kind of the phase-change material;

- the kind of encapsulation;

- the thermal characteristics and thermal stability of PCMs;

- the integration in building structures;

- the heat transfer.

Moreover, there is a requirement for a long-term stability of the storage medium and the PCM-container system. Other relevant aspects are the useful life of these systems and the number of cycles they can withstand without a degradation of their properties. ${ }^{6}$

The research and development at the Brno University of Technology dealing with thermal storage is focused on the integration of PCMs into building envelopes to provide a thermal comfort in the range required by the legislation. A micro-encapsulated paraffin-based PCM is

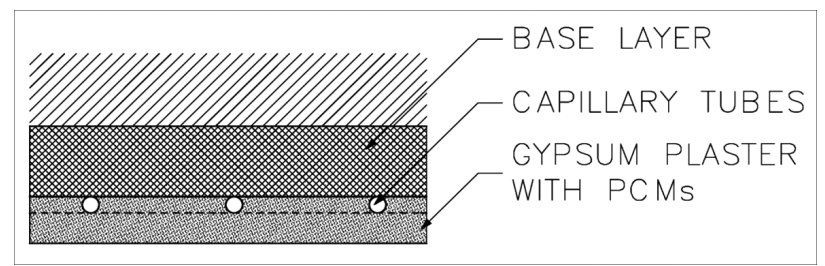

Figure 1: Detail of a heat-storage structure

Slika 1: Detajl strukture za shranjevanje toplote

used for this purpose. A team of investigators from the Brno University of Technology developed and patented heat-storage modules for a stabilization of the thermal environment in buildings. The composition of a module is shown in Figure 1.

The system can effectively stabilize the thermal microclimate in buildings with low operating costs. It allows not only a passive cooling of the rooms in summer, but it can also be used for a low-temperature heating in winter. The main technological components of the module are the basic slab, the heat-storage plaster and the capillary tubes for a thermal activation of the module. The system of the capillary tubes is placed in a layer of gypsum plaster with integrated micro-pellets containing a PCM for an advanced latent-heat/cold storage. Micronal@DS $5040 \mathrm{X}$ was used as the latent-heatstorage medium (PCM). The capillary tubes integrated in the heat-storage plaster were connected to the distribution and return pipes. It is necessary to provide a direct exposure of the heat-storage layer to the indoor environment for a good heat transfer; therefore, the heat-storage structures containing PCMs cannot be obstructed by furniture or suspended ceilings.

Gypsum plaster with a special composition for the proposed use was modified with a mass fraction $w=$ $30 \%$ of Micronal@DS 5040 X.

Two important properties were tested in the experiments:

- the change in the thermal characteristics of the PCM after 100 melting-freezing cycles;

- the change in the thermal conductivity of the plaster with the microencapsulated PCM.

The thermal-energy-storage properties, the thermal reliability and the thermal durability of the composite with the PCM were determined with differential scanning calorimetry (DSC). ${ }^{7}$

DSC is a widely used method from the group of thermal-analysis methods. Nowadays, DSC is used for thermal analyses of new materials, e.g., in the study of the phase changes and testing quality of polymer materials. DSC compensation is a method whose principle consists of measuring the temperature and the heat flux during the heating or cooling of a tested material. The process is realized at a constant rate of heating or cooling and carried out in a closed chamber. The test result can be used to determine the melting temperature of a sample the onset/offset of the phase-transition temperature - the 
crystallization, or various types of crystallization, the heat capacity and the temperature degradation. The differential scanning calorimeter is a twin instrument, comprising a sample and a reference calorimeter within a common thermal enclosure, where the two calorimeters are usually assumed to be identical. A PYRIS1 Perkin Elmer calorimeter was used in the tests.

Micronal®DS $5040 \mathrm{X}$ was tested before and after the thermal cycling. A sample of Micronal@DS 5040 X was placed in a glass laboratory test tube with a thermocouple sensor. The tube was immersed in liquid nitrogen until the temperature measured by the thermocouple dropped to $-10{ }^{\circ} \mathrm{C}$, then the tube was immersed in hot water $\left(60{ }^{\circ} \mathrm{C}\right)$. The tube remained in nitrogen and warm water for about $1 \mathrm{~min}$ and $1.5 \mathrm{~min}$. The whole procedure was repeated 100-times.

The heat transfer between the indoor environment and the heat storage depends mainly on the thermal conductivity of the plaster with the micro-encapsulated PCM. The thermal conductivity was determined with the guarded-hot-plate method. In this method a solid sample of a material is placed between two plates. One plate is heated and the other is cooled. The temperatures of the plates are monitored until they are constant. A constant heat flow flows through the test sample in the stationary-temperature state. The steady-state temperatures, the thickness of the sample and the heat input to the hot plate are used to calculate the thermal conductivity.

Several samples of gypsum plaster with various compositions were tested:

- referential sample (sample no. 0) - plain gypsum plaster;

- modified plaster (sample no. 1$)-w=68 \%$ gypsum plaster and $w=32 \%$ PCM;

- modified plaster (sample no. 2 ) $-w=65 \%$ gypsum plaster, $w=30 \%$ PCM and $w=5 \%$ natural graphite;

- modified plaster (sample no. 3) $-w=61.5 \%$ gypsum plaster, $w=29 \%$ PCM and $w=9.5 \%$ natural graphite;

- modified plaster (sample no. 4 ) $-w=67.9 \%$ gypsum plaster, $w=31.8 \%$ PCM and $w=0.3 \%$ expanded graphite;

- modified plaster (sample no. 5) $-w=67.7 \%$ gypsum plaster, $w=31.7 \%$ PCM and $w=0.6 \%$ expanded graphite.

\section{RESULTS AND DISCUSSION}

\subsection{Thermal stability of the latent-heat-storage me- dium}

The characteristics of all the samples were tested with DSC twice, before and after the cycling. The experiments were carried out at a temperature rate of 1.0 $\mathrm{K} / \mathrm{min}$. The onset and peak temperatures during the heating and cooling depend on the temperature rate. The melting temperatures rise with the temperature rate. The risk of supercooling rises with the heating rate.
The results are shown in Tables $\mathbf{1}$ and $\mathbf{2}$. Both tables show a minimum difference in the enthalpy of the phase change of the tested samples. The difference between the onset temperatures is $0.1 \mathrm{~K}$.

The DSC curves in Figure 2 show minimum differences between the characteristics of the samples.

Table 1: Characteristics of Micronal@DS 5040 X before thermal cycling

Tabela 1: Značilnosti Micronal®DS 5040 X pred toplotnim cikliranjem

\begin{tabular}{|l|c|c|}
\hline & Heating & Cooling \\
\hline Onset temperature, ${ }^{\circ} \mathrm{C}$ & 18.8 & 21.8 \\
\hline Peak temperature, ${ }^{\circ} \mathrm{C}$ & 24.5 & Multi-peak \\
\hline Enthalpy, $\mathrm{J} / \mathrm{g}$ & 96.2 & 92.6 \\
\hline
\end{tabular}

Table 2: Characteristics of Micronal®DS 5040 X after thermal cycling

Tabela 2: Značilnosti Micronal@DS 5040 X po toplotnem cikliranju

\begin{tabular}{|l|c|c|}
\hline & Heating & Cooling \\
\hline Onset temperature, ${ }^{\circ} \mathrm{C}$ & 18.9 & 21.9 \\
\hline Peak temperature, ${ }^{\circ} \mathrm{C}$ & 24.5 & Multi-peak \\
\hline Enthalpy, $\mathrm{J} / \mathrm{g}$ & 96.5 & 93.4 \\
\hline
\end{tabular}

\subsection{Thermal conductivity of the plaster with PCM}

Thermal conductivity is negatively influenced by the micro-encapsulated PCM. The increase in the thermal conductivity can be achieved with an addition of natural or expanded graphite. The influence of graphite on the thermal conductivity is shown in Table $\mathbf{3}$. As can be seen, the best material for the heat-conductivity improvement is natural graphite. A low amount of expanded graphite $(w=0.3 \%)$ has no positive effect on the heat conductivity.

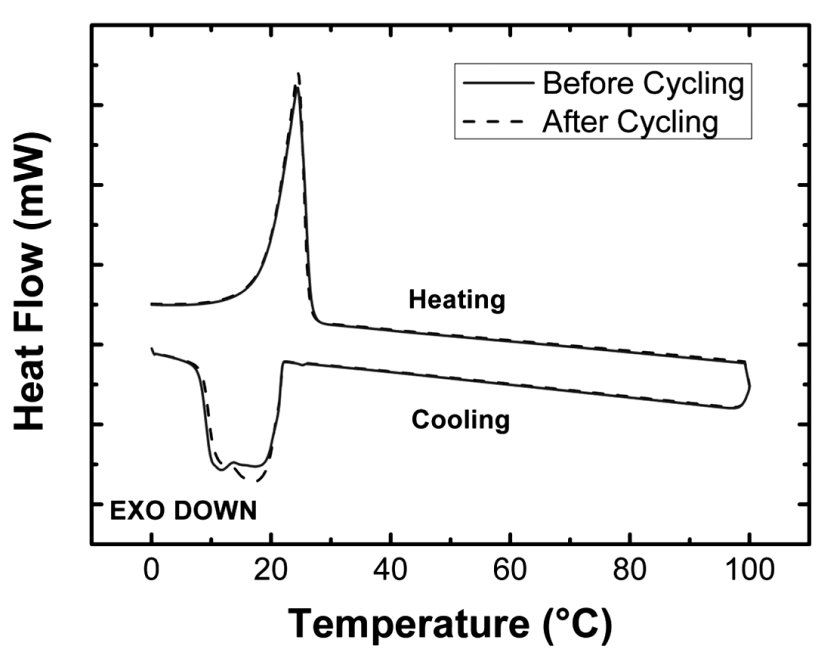

Figure 2: DSC results for Micronal®DS 5040 X before and after thermal cycling

Slika 2: Rezultati DSC za Micronal@DS 5040 X pred toplotnim cikliranjem in po njem 


\section{OSTRÝ et al.: MICRO-ENCAPSULATED PHASE-CHANGE MATERIALS FOR LATENT-HEAT STORAGE: ...}

Table 3: Thermal conductivity of plaster with different compositions Tabela 3: Toplotna prevodnost ometa pri različnih sestavah

\begin{tabular}{|l|c|c|}
\hline \multicolumn{1}{|c|}{ Number of sample } & $\begin{array}{c}\text { Pour density } \\
\text { of plaster } \\
\mathrm{kg} / \mathrm{m}^{3}\end{array}$ & $\begin{array}{c}\text { Thermal } \\
\text { conductivity } \\
\mathrm{W} /(\mathrm{m} \mathrm{K})\end{array}$ \\
\hline Referential sample (no. 0) & 1080 & 0.3866 \\
\hline Plaster with PCM (no. 1) & 677 & 0.1760 \\
\hline$w=5 \%$ natural graphite (no. 2) & 676 & 0.1996 \\
\hline$w=9.5 \%$ natural graphite (no. 3) & 665 & 0.2336 \\
\hline$w=0.3 \%$ expan. graphite (no. 4) & 647 & 0.1598 \\
\hline$w=0.6 \%$ expan. graphite (no. 5) & 589 & 0.1766 \\
\hline
\end{tabular}

\section{CONCLUSION}

The PCM used in the experiment did not significantly change its thermal properties even after 100 thermal cycles. From this point of view, the tested organic PCM is suitable for integration in building structures. The advantage of this kind of PCM is the possibility of integration in gypsum plaster that can be combined with capillary tubes for charging or discharging the heat. The modified plaster acting as a thermally activated layer can be used in radiant heating or cooling in residential buildings. However, the addition of a PCM causes a significant decrease in the thermal conductivity of the plaster. This problem can be overcome by adding natural graphite, e.g., $w=9.5 \%$ of natural graphite increased the thermal conductivity of the plaster with the PCM from $0.1760 \mathrm{~W} /(\mathrm{m} \mathrm{K})$ up to $0.2336 \mathrm{~W} /(\mathrm{m} \mathrm{K})$.

\section{Acknowledgement}

This work paper has been worked out under project No. P104/12/1838 "Utilization of latent heat storage in phase change materials to reduce primary energy consumption in buildings", supported by Czech Science Foundation and under the project No. LO1408 "AdMaS UP - Advanced Materials, Structures and Technologies", supported by Ministry of Education, Youth and Sports under the "National Sustainability Programme I".

\section{REFERENCES}

${ }^{1}$ F. Agyenim, N. Hewitt, F. Eames, M. Smyth, A review of materials, heat transfer and phase change problem formulation for latent heat thermal energy storage systems (LHTESS), Renewable and Sustainable Energy Reviews, 14 (2010) 2, 615-628, doi:10.1016/j.rser. 2009.10.015

${ }^{2}$ N. Soares, J. J. Costa, A. R. Gaspar, P. Santos, Review of passive PCM latent heat thermal energy storage systems towards buildings' energy efficiency, Energy and Buildings, 59 (2013), 82-103, doi:10.1016/j.enbuild.2012.12.042

${ }^{3}$ T. C. Ling, C. S. Poon, Use of phase change materials for thermal energy storage in concrete: An overview, Construction and Building Materials, 46 (2013), 55-62, doi:10.1016/j.conbuildmat.2013.04.031

${ }^{4}$ V. V. Tyagi, S. C. Kaushik, S. K. Tyagi, T. Akiyama, Development of phase change materials based microencapsulated technology for buildings: A review, Renewable and Sustainable Energy Reviews, 15 (2011) 2, 1373-1391, doi:10.1016/j.rser.2010.10.006

${ }^{5}$ L. Bayés-García, L. Ventola, R. Cordobilla, R. Benages, T. Calvet, M. A. Cuevas-Diarte, Phase Change Materials (PCM) microcapsules with different shell compositions: Preparation, characterization and thermal stability, Solar Energy Materials and Solar Cells, 94 (2010) 7, 1235-1240, doi:10.1016/j.solmat.2010.03.014

${ }^{6}$ B. Zalba, J. M. Marín, L. F. Cabeza, H. Mehling, Review on thermal energy storage with phase change: materials, heat transfer analysis and applications, Applied Thermal Engineering, 23 (2003) 3, 251-283, doi:10.1016/S1359-4311(02)00192-8

${ }^{7}$ A. Sari, A. Biçer, Preparation and thermal energy storage properties of building material-based composites as novel form-stable PCMs, Energy and Buildings, 51 (2012), 73-83, doi:10.1016/j.enbuild. 2012.04.010 